\title{
Control of Francisella tularensis Virulence at Gene Level: Network of Transcription Factors
}

\author{
Petra Spidlova $^{1, *(\mathbb{C})}$, Pavla Stojkova ${ }^{2}$, Anders Sjöstedt ${ }^{2}{ }^{2}$ and Jiri Stulik ${ }^{1}$ \\ 1 Department of Molecular Pathology and Biology, Faculty of Military Health Sciences, University of Defence, \\ Trebesska 1575, 50001 Hradec Kralove, Czech Republic; jiri.stulik@unob.cz \\ 2 Department of Clinical Microbiology, Umeå University, SE-901 85 Umeå, Sweden; \\ pavla.stojkova@gmail.com (P.S.); anders.sjostedt@umu.se (A.S.) \\ * Correspondence: petra.spidlova@unob.cz; Tel.: +420-973-253-223
}

Received: 17 September 2020; Accepted: 18 October 2020; Published: 21 October 2020

\begin{abstract}
Regulation of gene transcription is the initial step in the complex process that controls gene expression within bacteria. Transcriptional control involves the joint effort of RNA polymerases and numerous other regulatory factors. Whether global or local, positive or negative, regulators play an essential role in the bacterial cell. For instance, some regulators specifically modify the transcription of virulence genes, thereby being indispensable to pathogenic bacteria. Here, we provide a comprehensive overview of important transcription factors and DNA-binding proteins described for the virulent bacterium Francisella tularensis, the causative agent of tularemia. This is an unexplored research area, and the poorly described networks of transcription factors merit additional experimental studies to help elucidate the molecular mechanisms of pathogenesis in this bacterium, and how they contribute to disease.
\end{abstract}

Keywords: Francisella; virulence; transcription factor; pathogenesis; gene regulation

\section{Introduction}

Francisella tularensis belongs to the genus Francisella, which is highly diverse comprising a considerable number of species, and the genus is rapidly expanding. Several species exist globally and many species appear adapted to highly specialized environmental niches and are capable of infecting a broad range of mammals and fish. The species F. tularensis encompasses two subspecies pathogenic for humans, tularensis and holarctica. F. novicida is usually described as separate species, although it shares $>97 \%$ nucleotide identity with F. tularensis, the former is a rare human pathogen often derived from environmental sources [1]. However, F. novicida is often used as a surrogate for $F$. tularensis, e.g., in genetic studies. F. tularensis is a highly infectious human pathogen causing tularemia [2,3]. It is an intracellular pathogen, the virulence of which is based on the ability to escape from phagosomes and replicate in the cytosol of the host cell. Subsequently, after rapid intracellular replication, it subverts the immune system [4-8]. Depending on the route of infection, it may, in severe cases, cause pneumonia $[9,10]$. Its virulence is controlled at many levels, including molecular signaling, gene transcription, translation, and many posttranslational modifications. Its pathogenicity depends on the production of bacterial virulence factors, the role of which is to attack the host cell and to suppress the immune response.

The most important virulence factors of $F$. tularensis include the capsule $[11,12]$ and surface lipopolysaccharide layer [13-16]; membrane vesicles [6,17,18]; and secretion systems, especially the Type VI Secretion System (T6SS) [19-22]. The latter is composed of proteins encoded by genes from the Francisella pathogenicity island (FPI) ( $p d p A B C D E$, iglABCDEFGHIJ, vgrG, DotU domain-containing protein $(\operatorname{dot} U))[20,23,24]$. FPI proteins are necessary for Francisella intracellular replication and 
mutant strains lacking at least one FPI gene are also defective for virulence in vivo [21]. FPI proteins are key components that ensure the ability of F. tularensis to modulate phagosome maturation and to escape into the cytosol of the host cell [21], as exemplified by analysis of the best described FPI protein, intracellular growth locus C (IglC) [25]. Interestingly, not all FPI proteins are important for intracellular growth, as reported for IglG [21]; nevertheless, a $\Delta i g l G$ mutant strain exhibited delayed phagosomal escape [26]. FPI gene expression is probably the most important step of Francisella virulence and a detailed understanding of its regulation is essential for the understanding of the F. tularensis pathogenesis.

Last but not least virulence factors are regulatory proteins that control the transcription of virulence genes, mainly the macrophage growth locus, subunit A (MglA)/stringent starvation protein A (SspA)/pathogenicity island gene regulator (PigR) complex [27-32], but also numerous others. Many DNA-binding proteins have been identified in Francisella since its complete genome sequencing [24], but only a few of them are well described and reviewed in Reference [33]. This review will be focused on transcription factors that are important for Francisella pathogenesis (Table 1).

Table 1. Transcription regulators described in this review.

\begin{tabular}{|c|c|c|c|c|c|}
\hline & Locus Tag & & Gene & Main Function & Reference \\
\hline Schu S4 & LVS & U112 & & & \\
\hline FTT_1275 & FTL_1185 & FTN_1290 & $m g l A$ & $\begin{array}{l}\text { interacting with SspA, regulation of FPI genes, necessary for } \\
\text { intracellular replication }\end{array}$ & {$[27-30,34,35]$} \\
\hline FTT_0458 & FTL_1606 & FTN_0549 & $\operatorname{ssp} A$ & $\begin{array}{l}\text { interacting with MglA, regulation of FPI genes, necessary } \\
\text { for stress response }\end{array}$ & {$[28,30,34,36]$} \\
\hline FTT_0383 & FTL_0449 & FTN_0480 & $\operatorname{pigR}$ & interacting with $\mathrm{MglA} / \mathrm{SspA}$, regulation of FPI genes & {$[31,32,37-41]$} \\
\hline FTT_0630 & FTL_0898 & FTN_1051 & $h f q$ & $\begin{array}{l}\text { RNA-binding protein, necessary for stress response, } \\
\text { negative regulator of } p d p \text { operon }\end{array}$ & [43-45] \\
\hline FTT_0748 & FTL_1364 & FTN_0720 & $i c l R$ & important only for F. novicida virulence in vivo & [46-48] \\
\hline FTT_0556c & FTL_1014 & FTN_0959 & $o x y R$ & regulation of genes involved in oxidative stress response & {$[49,50]$} \\
\hline FTT_1255c & FTL_0689 & FTN_1274 & $\operatorname{araC}$ & $\begin{array}{l}\text { global regulator, active during oxidative stress conditions, } \\
\text { regulation of some FPI genes and tricarboxylic acid (TCA) } \\
\text { cycle during oxidative stress }\end{array}$ & [51] \\
\hline FTT_1442c & FTL_0616 & FTN_1412 & rpoA2 & RNAP subunit A2, gene transcription & {$[30,56]$} \\
\hline FTT_0144 & FTL_1744 & FTN_1568 & $r p o B$ & RNAP subunit $\beta$, gene transcription & [30] \\
\hline FTT_0145 & FTL_1743 & FTN_1567 & rpoc & RNAP subunit $\beta^{\prime}$, gene transcription & [30] \\
\hline FTT_0703 & FTL_1533 & FTN_0613 & rpoZ & RNAP subunit $\omega$, gene transcription & [30] \\
\hline FTT_1035c & FTL_1050 & FTN_0913 & $r p o D$ & sigma factor 70, major sigma factor & {$[30,57]$} \\
\hline FTT_1112c & FTL_0851 & FTN_1092 & rpoH & sigma factor 32 , regulation of heat shock proteins & {$[30,57-59]$} \\
\hline FTT_1557c & FTL_0552 & FTN_1465 & $p m r A / q s e B$ & $\begin{array}{l}\text { response regulator, important for biofilm formation in } \\
\text { F. novicida, intracellular replication, interacting } \\
\text { with } \mathrm{MglA} / \mathrm{SspA}\end{array}$ & [60-64] \\
\hline
\end{tabular}

\section{Transcription Factors Involved in Regulation of the FPI}

\subsection{MglA/SspA Complex Directly Regulates FPI}

One of the best described transcriptional regulators of F. tularensis is the MglA protein (macrophage growth locus, subunit A). The protein was identified as necessary for F. novicida replication in host cells $[34,35]$ and a mutant strain lacking the $m g l A$ gene is attenuated in a mouse model of infection. Notably, the mutant does not elicit a protective immune response against infection with the fully virulent parental F. tularensis strain [27,28]. MglA is a transcription factor, which regulates up to 100 genes, including the FPI genes [27-29]. The most important genes that are associated with $F$. tularensis or F. novicida virulence and are known to be positively regulated by MglA are listed in Table 2. 
Table 2. Genes that are associated with Francisella tularensis or Francisella novicida virulence and are positively regulated by macrophage growth locus, subunit A (MglA).

\begin{tabular}{lclc}
\hline \multicolumn{1}{c}{ Locus Tag } & Gene & \multicolumn{1}{c}{ Description } & Reference \\
\hline FTT_1344 & $p d p A$ & FPI, Pathogenicity determinant protein A & {$[28]$} \\
FTT_1345(FTN_1310) & $p d p B$ & FPI, Pathogenicity determinant protein B & {$[28,29]$} \\
FTT_1346 & $i g l E$ & FPI, Intracellular growth locus E & {$[28]$} \\
FTT_1347 & vgrG & FPI, Valine-glycine repeat protein G & {$[28]$} \\
FTT_1348 & $i g l F$ & FPI, Intracellular growth locus F & {$[28]$} \\
FTT_1349 & $i g l G$ & FPI, Intracellular growth locus G & {$[28]$} \\
FTT_1350 & $i g l H$ & FPI, Intracellular growth locus H & {$[28]$} \\
FTT_1351 & dotU & FPI, DotU domain-containing protein & {$[28]$} \\
FTT_1352 & $i g l I$ & FPI, Intracellular growth locus I & {$[28]$} \\
FTT_1353 & $i g l J$ & FPI, Intracellular growth locus J & {$[28]$} \\
FTT_1354 & $p d p C$ & FPI, Pathogenicity determinant protein C & {$[28]$} \\
FTT_1355 & $p d p E$ & FPI, Pathogenicity determinant protein E & {$[28]$} \\
FTT_1356c & $i g l D$ & FPI, Intracellular growth locus D & {$[28]$} \\
FTT_1357c (FTN_1322) & iglC & FPI, Intracellular growth locus C & {$[28,29]$} \\
FTT_1358c (FTN_1323) & $i g l B$ & FPI, Intracellular growth locus B & {$[28,29]$} \\
FTT_1359c (FTN_1324) & $i g l A$ & FPI, Intracellular growth locus A & {$[28,29]$} \\
FTT_1360c (FTN_1325) & $p d p D$ & FPI, Pathogenicity determinant protein D & {$[28,29]$} \\
FTN_1051 & hfq & Host factor for bacteriophage Q $\beta$ RNA replication & {$[29]$} \\
FTN_0549 & sspA & Stringent starvation protein A & {$[29]$} \\
FTN_1054 & hupB & DNA-binding protein HU-beta & {$[29]$} \\
\hline
\end{tabular}

The MglA protein directly interacts with the SspA protein (Stringent starvation protein A), and this interaction is unique for Francisella genus. The heterodimer MglA/SspA further binds to RNA polymerase (RNAP). In other bacteria, SspA interacts with RNAP as a homodimer [39]. The activity of SspA was especially notable during starvation conditions and its transcription activity is connected with genes that are important and necessary during various stress conditions [28,34]. The regulons of MglA and SspA are similar and both proteins are involved in the regulation of virulence genes in Francisella, including FPI genes. MglA and SspA interact with each other to form a complex with the RNA polymerase, which is essential for activation of the FPI genes [30]. Structural and biochemical analysis showed that MglA is able to form homodimers, but it exhibits a preference for heterodimer formation with SspA [36]. SspA homologs exist in several bacteria and have consistently been associated with virulence [67-70], whereas MglA is a protein unique for Francisella [36]. In E. coli, during the stationary phase, SspA inhibits the level of the global regulator H-NS (histone-like nucleoid structuring), which acts mostly as a repressor, and thus SspA induces stress defense mechanisms, including protection against acid and starvation stress [71]. The importance of MglA for adaptation to oxidative stress was also reported for the $F$. tularensis live vaccine strain (LVS) strain [72].

\subsection{PigR (FevR) and Guanosine Tsetraphosphate (ppGpp) Interact with the MglA/SspA Complex}

Following the discovery of the MglA/SspA regulatory complex, the detailed molecular mechanisms on how this complex interacts with DNA were elucidated. It was shown that FevR (Francisella effector of virulence regulation) is required for expression of FPI genes from the MglA/SspA regulon, and that the expression of $f e v R$ is upregulated by MglA and FevR/MglA together upregulated virulence gene expression. Subsequently, the importance of FevR for intracellular replication of F. novicida and its virulence in vivo was described [31]. A later study confirmed the involvement of FevR in regulating FPI gene expression also in F. tularensis, where the ortholog was denoted as PigR. It was confirmed that there was direct interaction between PigR and the MglA/SspA complex and that this interaction was promoted by guanosine tetraphosphate (ppGpp) [32] in the presence of $\mathrm{Mg}^{2+}$ [39]. A later study showed that MglA/SspA must be bound to ppGpp to mediate high-affinity interactions with PigR, and that the MglA/SspA complex interacts with the last 22 residues of the PigR-terminal domain [39]. The importance of the interaction between PigR and the MglA/SspA complex has been demonstrated 
to be necessary for the coordinate control of virulence genes [31,32,37]. Another signal molecule, inorganic polyphosphate (polyP), was identified to be important for MglA/SspA and interactions between target genes and promoters. It was shown that the absence of polyP led to decreased binding of the MglA/SspA complex to the promoters of the pathogenicity determinant protein $\mathrm{D}(p d p D)$, intracellular growth locus A (iglA), fevR, and $p p K$ genes [40]. Although PigR is able to associate with many promoters, only promoters that contain a specific sequence motif referred to as the PigR-response element (PRE) are positively regulated by PigR/MglA/SspA [38].

In E. coli, ppGpp is a small regulating molecule that binds directly to the RNA polymerase (RNAP) and could thus both positively and negatively regulate transcription of genes [73]. The level of ppGpp in the bacterial cell is regulated by the ppGpp synthetase (RelA) and a bifunctional protein that is able to synthesize and degrade ppGpp, named SpoT [74]. relA and spoT genes were identified in the F. novicida [75] and also in the F. tularensis Schu S4 [24,76] genome. The level of ppGpp in F. novicida was affected by a relA gene deletion [76], and the deletion of both the $\operatorname{rel} A$ and spoT genes led to the complete disappearance of ppGpp [32].

pigR expression is positively regulated by MigR (macrophage intracellular growth regulator) [32], and MigR was found to be necessary for the alarmone ppGpp accumulation [41]. Moreover, MigR is necessary for effective replication of the LVS strain in macrophages [41]. MigR also regulates the iglABCD expression [77], but it lacks a DNA-binding domain, suggesting it does not play a role as a transcription factor and, therefore, its effect on pigR and $i g l A B C D$ is indirect. MigR could play a role in the regulation of RelA and SpoT and thereby indirectly influence the ppGpp synthesis [32]. Among others, MigR is involved in the ability of $F$. tularensis to block NADPH oxidase activity in neutrophils [77].

\section{Regulators Participating in the Oxidative and Nitrosative Stress Responses}

\subsection{OxyR Regulates Genes Involved in the Oxidative Stress Response}

The OxyR (hydrogen peroxide-inducible genes activator) transcription factor is a member of the LysR transcriptional regulator family. Similar to other regulatory DNA-binding proteins, members of this family possess the helix-turn-helix (HTH) domain. OxyR is a well-known regulatory protein in E. coli, where its activity counteracts the actions of reactive oxygen species and regulates the expression of many genes in response to a variety of stress stimuli [78]. OxyR is important for F. tularensis subsp. holarctica LVS strain during the oxidative stress response. It was found that the loss of OxyR leads to a lower ability to grow inside macrophages and attenuated virulence in mice [49]. OxyR regulates the expression of the $a h p C$, $k a t G$, and superoxide dismutase ( $\operatorname{sodB}$ ) genes, which act as antioxidant enzymes in Francisella. It is able to bind directly to the promoter of $a h p C$ and kat $G[49,50]$. Mainly, KatG and OxyR work together and constitute an important system for defense against oxidative stress [79].

\subsection{Francisella Gene Regulation in the Nitrosative Stress Response}

Gene regulation in response to nitrosative stress is poorly studied in Francisella species. As mentioned above, AhpC, which is directly regulated by OxyR [49,50], is involved in resistance to reactive nitrogen species (RNS) as reported for the Schu S4 and LVS strains [80].

It was also shown that $F$. tularensis is able to change gene expression in response to spermine, a donor of NO molecule (nitrogen monoxide) [81]. Spermine belongs to polyamines that are associated with DNA synthesis, and spermine is produced only by eukaryotic cells [82]. Spermine induces gene expression of Francisella insertion sequences (IS), ISFtu1 and ISFtu2 [81]. IS are small genetic elements that are able to join to multiple DNA sites and thus alter gene expression [83]. Not only that spermine is able to induce the expression of ISFtu1 and ISFtu2 but also the expression of genes downstream to IS element. On the other hand, expression of some Francisella genes can be decreased in response to spermine (iglA, iglC, and iglD) [81]. 


\subsection{The RNA-Binding Protein Hfq}

The Hfq protein was found to be a necessary host factor required for the synthesis of bacteriophage $\mathrm{Q} \beta$ RNA in E. coli [84]. Hfq is not an ordinary transcription factor due to its preferences to bind RNA rather than DNA. Nevertheless, Hfq was identified as a bacterial nucleoid-associated protein, suggesting it has a role as a transcription factor [85]. An ability to directly bind DNA by its $C$-terminal part was demonstrated in E. coli [86]. Hfq is present in the nuclear, cytoplasmic, and membrane fractions in E. coli [87], however, its amount varies among the fractions. The largest amounts of Hfq are found in the cytoplasmic and membrane fractions with $30 \%$ and $50 \%$, respectively, whereas only $10-20 \%$ is present in the nuclear fraction [87]. Its presence close to the DNA chain was also confirmed by electron microscopy [87]. It was suggested that Hfq is a sequence non-specific DNA-binding protein and that the number of binding sites increases with higher concentrations of $\mathrm{Hfq}[85,86]$, although a putative Hfq-binding motif has been proposed [86]. Nevertheless, Hfq is predominantly referred to as an RNA-binding protein and plays a key role in the pathogenesis of virulent bacteria such as Yersinia pseudotuberculosis [88], Neisseria meningitides [89], and Salmonella enterica [90]. Hfq is also known for its role in promoting sRNA-mRNA interactions that could be important for the bacterial response to various environment conditions (iron limitation, oxidative stress, anaerobic conditions, glucose starvation) [91]. In support of this hypothesis, Hfq interacts with the sRNA of DsrA (dissimilatory sulfite reductase subunit A) and mRNA of RpoS (RNA polymerase sigma factor), thereby participating in the regulation of the stress response factor RpoS in E. coli [92].

The Hfq protein is also indispensable in Francisella. Hfq is important for stress tolerance and full virulence in F. tularensis subsp. holarctica, where it plays a role as a pleiotropic regulator [43] under control of sigma factor 70. It regulates the expression of a multitude of genes, including the FPI genes. Interestingly, Hfq regulates only one ( $p d p)$ of the two FPI operons ( $p d p$ and $i g l)$. Hfq acts, in most cases, as a negative regulator, as suggested by a study at the transcriptomic level in F. tularensis. The expression of genes from the $p d p$ operon was upregulated at the transcriptomic level in a $\Delta h f q$ mutant strain, suggesting Hfq is their negative regulator in the wild-type context [43]. A proteomic study revealed decreased levels of the FPI proteins due to an $h f q$ gene deletion, which explains why an $h f q$ mutant is attenuated [44]. The importance of Hfq in stress tolerance was observed also in F. novicida [45].

\section{Global Regulatory Proteins Important for F. tularensis Virulence}

\subsection{The HU Protein: A Small Unit Necessary for F. tularensis Virulence}

Similar to eukaryotic histones, which are responsible for the alteration of the DNA structure and gene regulation, bacteria contain small basic regulatory proteins called histone-like proteins, more precisely nucleoid-associated proteins due to their localization in bacterial cells. It is presumed that they play the same role in the cell as their eukaryotic counterparts [93]. They bind DNA and by bending DNA chains they are able to alter gene expression. Among this group of DNA-binding proteins belongs HU (histone-like factor U), FIS (factor for inversion stimulation), H-NS (histone-like nucleoid structuring), and IHF (integration host factor) proteins [94]. HU and IHF proteins are homologous and are strongly conserved among bacterial species. Additionally, the HU protein enhances the DNA-binding capacity of IHF [95]. Their roles in the cell are indispensable and disruption or malfunction of one of them could lead to the alteration of basic metabolic pathways or even attenuation of virulence of pathogenic bacteria.

Although the HU protein has been well studied in Gram-negative bacteria other than $F$. tularensis [reviewed in Reference 47], its significance for F. tularensis subsp. holarctica intracellular growth and virulence was elucidated only recently [42]. HU forms heterodimers in most bacteria studied (e.g., Enterobacteriaceae) and is encoded by two genes hupA and hupB [93], but in some bacteria (e.g., F. tularensis, M. tuberculosis) [42,96,97], HU is encoded by a single hupB gene and forms homodimers. The HU protein is known to be abundant in the bacterial cell [85], where it is able to influence 
recombination, replication, transcription, and DNA shape [98,99]. Moreover, the HU protein is capable to modulate the interaction between the IHF nucleoid-associated protein and its target DNA sequence in the oriC gene; thereby, HU contributes to DNA replication in E. coli [100]. The HU protein binds all nucleic acids in a non-specific manner [101], but it shows higher preferences for abnormal structures, such as four-way junctions or replication forks [102]. By binding to DNA, HU ensures its negative supercoiling, whereby it contributes to the regulation of gene expression [103]. The HU-DNA interaction also provides protection of DNA against free hydroxyl radicals that could irreversibly damage DNA [42,104]. DNA-binding sites of HU are of different lengths in various bacteria [95,99,105-107], but preferences for A/T rich sites have been identified [108]. It has been suggested that HU is not a specific transcription regulator, but rather that it acts as a separator of transcription units by its ability of DNA supercoiling, and thus it can influence gene transcription, either as a positive or negative regulator [109].

$\mathrm{HU}$ functions as a transcription factor inside the bacterial cell, but it is also secreted extracellularly. In Pseudomonas, HU was found as a component of biofilm formed by the bacterium [110]. It is also secreted by Wolbachia directly into the host cell nucleus, where it binds host DNA [111]. In F. tularensis subsp. holarctica LVS, HU was found to be secreted since it was identified in the culture filtrate [112] and constituted a minor component of secreted outer membrane vesicles (OMV) [18]. HU is necessary for the F. tularensis subsp. holarctica FSC200 strain intracellular replication and virulence in mice [42]. It was also proven that it is able to bind dsDNA and, thereby, protect against hydroxyl radicals. Deletion of the hupB gene (encoding HU protein) led to the downregulation of PigR and several FPI proteins as well as to the downregulation of $p i g R$ and several FPI genes. An F. tularensis mutant strain lacking hupB gene is attenuated in vitro and in vivo as well, demonstrating that $\mathrm{HU}$ is important for Francisella virulence [42].

Recently, Milanez et al. [113] observed that a $\triangle h u p A B$ mutant of Salmonella enterica Enteritidis is highly attenuated and can induce protection against wild-type challenge and thus could be explored as a potential live vaccine. HU proteins are highly conserved among bacterial species $[85,96]$ and it is, therefore, likely that they, as for Salmonella, contribute to virulence in many bacterial species and an $F$. tularensis HU mutant may be a potential live vaccine strain candidate.

\subsection{AraC, a Novel Global Regulator}

The AraC protein (arabinose operon regulatory protein) belongs to the AraC/XylS family that is characterized by the presence of the HTH DNA-binding domain. This domain is conserved in all members of this family and is necessary for the protein's function as a transcription factor. The evidence of the HTH motif in F. tularensis subsp. holarctica LVS AraC was confirmed by sequence alignment. Subsequently, a mutant strain lacking the gene encoding AraC was characterized [51]. It was revealed that $\mathrm{AraC}$ is necessary for regulation of the oxidative stress response and that $\mathrm{AraC}$ is activated only during the oxidative stress conditions. It was also shown that AraC downregulates five FPI genes (pathogenicity determinant protein $\mathrm{E}(p d p E), p d p C$, iglJ, iglI, and $d o t U$ ) during oxidative stress, but not during normal physiological conditions. Transcriptome analysis of the mutant strain also revealed the involvement of $\mathrm{AraC}$ in the regulation of $\operatorname{aro} A$ and $r n h A$ (heat stress response and homeostasis) during oxidative stress conditions. AraC also plays a crucial role in the regulation of some key components of the TCA cycle during oxidative stress conditions [51]. The connection of the TCA cycle with F. tularensis subsp. holarctica LVS virulence has been described [114]. Pyruvate dehydrogenase and oxoglutarate dehydrogenase were downregulated in an araC deletion mutant strain during oxidative stress conditions [51]. Moreover, $\mathrm{AraC}$ regulates the pantothenate synthesis that is a central component of coenzyme A, a molecule necessary for the TCA cycle. It was also observed to be involved in glucose metabolism [51]. Thus, AraC seems to be a global regulator with many functions. AraC could affect RNA polymerase subunits expression, because RpoB and RpoC (RNA polymerase subunit $\beta$ and $\beta^{\prime}$ ) were downregulated in the ara $C$ mutant strain after exposure to various stress conditions, indicating that $\mathrm{AraC}$ is a positive regulator of these two proteins. A recent study regarding the AraC describes 
its possible important role in the pathogenesis of F. tularensis subsp. holarctica LVS strain. However, there is no proof that there is an AraC-DNA interaction in F. tularensis and this needs to be further explored [51].

\section{Regulators Necessary for Regulation of Iron and Metabolism}

\subsection{Ferric Uptake Regulator, Fur}

The ferric uptake regulator (Fur) crystal structure was described, and the ability of Fur to bind to promoter sequences containing a Fur box was demonstrated [52]. Fur is a tetrameric protein that is able to bind specific DNA sequences by its splitting into two dimers [52].

Fur is an important component involved in the regulation of iron concentration and contributes to metal homeostasis in the bacterial cell. The concentration of iron is limiting for optimal growth and physiological balance of bacteria, but higher concentrations could be fatal, therefore, it is highly regulated. The activity of Fur and the intracellular concentration of iron affect many key components critical for the virulence of pathogenic bacteria $[115,116]$. Fur works mainly as a Fe ${ }^{2+}$-dependent transcriptional repressor, but some genes require Fur for their expression [117]. It is necessary for the regulation of several genes involved in the tricarboxylic acid cycle $(\operatorname{frd} A B D, \operatorname{ssp} A, \operatorname{sucCD}, f u m A B)[118]$ and superoxide dismutase (SodB) as well [119]. Regulation of iron homeostasis and the functioning of metallo-regulating proteins are crucial for the Francisella physiology [54,55]. The level of host cell iron influences F. tularensis subsp. holarctica LVS intracellular replication and virulence [120]. On the other hand, if grown under iron-restricted conditions, F. tularensis subsp. holarctica LVS and F. tularensis subsp. tularensis Schu S4 were found to produce their own siderophores [53], FslA, which is similar to the polycarboxylate siderophore rhizoferrin [53]. Later, it was found that FslE is also required during iron starvation and could act as a membrane receptor for FslA [121]. The encoding genes belong to $f s l A B C D E F$ operon (also called fig operon), which is under Fur control [52] and upregulated during iron starvation [52,53]. Fur is required for full virulence of F. tularensis subsp. holarctica in both macrophage-like cells and mice [52].

\subsection{IclR Does Not Contribute Significantly to the F. tularensis Virulence}

The IclR family of transcription factors is widely distributed in bacteria and their characteristic feature is the presence of a helix-turn-helix (HTH) domain [122], which allows the protein to bind to the major groove of the DNA chain [123]. The role of the IclR protein for Francisella virulence and pathogenesis has been studied and while IclR is essential for the virulence of F. novicida in a mouse model of infection [47], it is dispensable for full virulence of F. tularensis subsp. holarctica or F. tularensis subsp. tularensis, despite that the IclR proteins are highly conserved among Francisella species [48]. A possible interaction of IclR with RipA at the protein level was identified in F. tularensis, suggesting that the RipA membrane protein could affect the IclR transcriptional activity [46].

\section{Proteins Essential for Gene Transcription}

RNA Polymerase Subunits and Sigma Factors

Critical and absolutely necessary for gene transcription is the RNA polymerase and sigma factors that ensure specific promoter recognizing by the RNA polymerase. The Francisella RNA polymerase is composed of two $\alpha$ subunits, the $\beta, \beta^{\prime}$ and $\omega$ subunits (rpoA1, rpoA2, rpoB, rpoC, rpoZ, respectively) [30]. Francisella contains two rpo $A$ genes that encode two non-identical $\alpha$ subunits, which are able to form both a heterodimer and a homodimer [30,56]. In addition, Francisella contains at least two sigma factors. The major sigma factor $\sigma^{70}$ is encoded by the $r p o D$ gene and an alternative sigma factor, which is a homolog of the $\sigma^{32}$ heat-shock family proteins, is encoded by the rpoH gene [30,57]. Transcripts of several genes were observed to have increased level of expression during heat shock (Hsp40, GroEL, GroES, DnaK, DnaJ, GrpE, ClpB, ClpX, ClpP, and HtpG), and six of them were found to be more 
abundant during overproduction of RpoH in the live vaccine strain (LVS) (Hsp40, HptG, DnaK, DnaJ, GroES, and GroEL) [57], which are proteins included in the heat stress response and are designated as heat-shock proteins (HSP) [57]. The HSP proteins are under direct regulation of RpoH in E. coli [58], suggesting the same model of gene regulation during heat shock conditions in F. tularensis subsp. holarctica LVS [57]. The response to heat shock is crucial for intracellular bacteria such as Francisella. Most of the RNA-polymerase-regulated genes are required for intracellular growth and full virulence of F. novicida [124]. Probably the most important of them is ClpB [125] that directly interacts with DnaK, which is under $\mathrm{RpoH}$ control, [59] and a strain defective for the $c l p B$ gene is an auspicious candidate as a live vaccine strain $[126,127]$.

\section{Response Regulators Involved in Two-Component Systems Work as Transcription Factors}

Several important DNA-binding proteins participating in Francisella pathogenicity are also response regulators and parts of two-component systems (TCSs). TCS is usually composed of a membrane-bound sensor histidine kinase and a DNA-binding response regulator. TCS is an important part of the transmission of an external signal to a bacterial cell and the subsequent appropriate response to changing environmental conditions through altering the level of gene expression [128,129]. If the membrane sensor kinase detects an external signal, its phosphorylation occurs. After the transfer of the phosphate group to the response regulator, it is activated and acts as a transcription factor. The response regulator is composed of two domains, a receiver, which is responsible for the phosphate group acceptation, and a DNA-binding domain [130]. So far, only three response regulators have been identified in Francisella, the response regulator PmrA (or its homolog QseB), the response regulator $\mathrm{KdpE}$, and biofilm-regulating Francisella protein regulator BfpR (or homolog in F. tularensis FTT_1543) [24]. The occurrence of TCS is different in the F. tularensis species and subspecies. Two complete (FTN_1452/FTN_1453 and KdpD/E) and one orphan TCSs (PmrA/QseC) are present in F. novicida, whereas no complete TCS was found in F. tularensis Schu S4. The sensor kinase FTT_1544 and response regulator KdpE are pseudogenes and FTT_1543, the sensor histidine kinase KdpD, PmrA, and the sensor histidine kinase QseC are orphan TCS components in the Schu S4 strain. F. tularensis subsp. holarctica FSC200 and LVS have only one response regulator PmrA and one orphan sensor kinase QseC [129,131].

\subsection{QseB/PmrA Response Regulator}

QseB, or its homolog PmrA, can be found in all Francisella species. Inactivation of $p m r A$ gene in F. novicida led to reduced survival and growth within human and murine macrophages, and the mutant strain was able to elicit a protective immune response against $F$. novicida wild-type challenge. The first analyses showed that PmrA regulates up to 148 genes, including FPI genes [132,133]. The importance of PmrA in biofilm formation was also described [60]. PmrA is a DNA-binding protein and following phosphorylation, it recognizes its own promoter and also the promoter of the FPI protein PdpD. The histidine kinase that is primarily responsible for phosphorylation of PmrA in F. novicida is $\mathrm{KdpD}$ [61]. The orphan sensor kinase QseC was also demonstrated to be important for PmrA phosphorylation and Francisella virulence [61].

The response regulator PmrA was observed to be important for survival and replication within the macrophages for both F. tularensis and F. novicida. PmrA works as both a positive and negative regulator. As already mentioned, PmrA participates in F. novicida biofilm formation due to the induction of diguanylate cyclase and phosphodiesterase expression. These enzymes are key regulatory components of biofilm formation [60,62]. PmrA is able to bind to the $p d p D$ promoter in F. novicida, and interaction between PmrA and the MglA/SspA complex was described, suggesting the involvement of PmrA in FPI gene regulation [61]. According to a recent study, PmrA could be a nucleoid-associated protein. It was found that PmrA is able to bind to 252 regions on chromosomal DNA in the F. tularensis LVS strain but directly influences only a few of them, mainly as a repressor. PmrA is able to repress the expression of the priM gene by direct binding to its promoter, which leads to the ability of F. tularensis 
to grow intracellularly. PriM is referred to as PmrA-repressed inhibitor of intramacrophage growth and it was described as an anti-virulence factor, the expression of which leads to downregulation of intracellular growth [63]. However, the latter was very recently revised [64]. Although, in the first study, PriM was detected as an anti-virulence determinant, because the deletion of the priM gene restored an F. tularensis subsp. holarctica LVS ability to survive within macrophages [63], the second study reported that double deletion mutant strain of pmrA (repressor of PriM) and priM did not restore the virulence phenotype, suggesting that loss of anti-virulence effect of PriM is caused by an unknown mechanism [64].

\section{2. $K d p E$}

$\mathrm{KdpE}$, a response regulator transcription factor, interacts with the sensor kinase KdpD in many bacteria, and the $\mathrm{KdpE} / \mathrm{KdpD}$ system is associated with the cellular regulation of potassium [65]. The presence of $\mathrm{KdpE} / \mathrm{KdpD}$ was confirmed also in the F. novicida genome, but detailed studies are missing. Mutant strains defective in the $k d p E$ or $k d p D$ genes are attenuated in animal models $[47,65]$. In other bacteria, the $\mathrm{KdpE} / \mathrm{KdpD}$ system is responsible for regulating the bacterial response to a variety of stress stimuli, and the DNA-binding activity of KdpE could play a key role in virulence and pathogenesis [65].

\subsection{Biofilm-Regulating Francisella Protein Response Regulator-BfpR}

Recently, a response regulator that is involved in biofilm formation in F. novicida was characterized and was denoted BfpR (Biofilm-regulating Francisella protein regulator). The presence of two domains, a REC- and a DNA-binding, was confirmed, suggesting it is a typical response regulator with transcription factor activity that is part of a TCS in Francisella. BfpR is encoded by the FTN_1452 gene and it is encoded in an operon with the FTN_1453 sensor kinase, thus, constituting another TCS in Francisella. BfpR has a negative effect on biofilm production, but it is a positive regulator of antimicrobial peptide resistance. The study also suggested that BfpR could be a negative regulator of iglC expression [66].

\section{Conclusions}

It is clear that Francisella, like other bacteria, possesses a large number of regulatory proteins, the action of which can lead to fine-tuned adaptation to changing environmental conditions. As an important human pathogen, it must be prepared to overcome all of the pitfalls generated by the immune system. Thus, these regulatory proteins might be key components for sustaining Francisella virulence. However, our knowledge is still incomplete and further in-depth studies of these proteins are needed to fully understand the pathogenesis of Francisella and to devise successful strategies to counteract infection with F. tularensis.

Author Contributions: Writing-original draft preparation, P.S. (Pavla Stojkova) and P.S. (Petra Spidlova); writing-review and editing, A.S. and J.S. All authors have read and agreed to the published version of the manuscript.

Funding: This work was supported by a Ministry of Defence of the Czech Republic-Long-term organization development plan, Medical Aspects of Weapons of Mass Destruction, of the Faculty of Military Health Sciences, University of Defence.

Conflicts of Interest: The authors declare no conflict of interest.

\section{References}

1. Rohmer, L.; Fong, C.; Abmayr, S.; Wasnick, M.; Larson Freeman, T.J.; Radey, M.; Guina, T.; Svensson, K.; Hayden, H.S.; Jacobs, M.; et al. Comparison of Francisella tularensis genomes reveals evolutionary events associated with the emergence of human pathogenic strains. Genome Biol. 2007, 8, R102. [CrossRef] [PubMed]

2. McCoy, G.W.; Chapin, C.W. Further Observations on a Plague-Like Disease of Rodents with a Preliminary Note on the Causative Agent, Bacterium tularense. J. Infect. Dis. 1912, 10, 61-72. [CrossRef] 
3. Francis, E. Tularemia Francis 1921: A new Diseasae of Man. J. Am. Med. Assoc. 1922, 78, 1015-1018.

4. Checroun, C.; Wehrly, T.D.; Fischer, E.R.; Hayes, S.F.; Celli, J. Autophagy-mediated reentry of Francisella tularensis into the endocytic compartment after cytoplasmic replication. Proc. Natl. Acad. Sci. USA 2006, 103, 14578-14583. [CrossRef] [PubMed]

5. Clemens, D.L.; Lee, B.-Y.; Horwitz, M.A. Virulent and avirulent strains of Francisella tularensis prevent acidification and maturation of their phagosomes and escape into the cytoplasm in human macrophages. Infect. Immun. 2004, 72, 3204-3217. [CrossRef]

6. Golovliov, I.; Baranov, V.; Krocova, Z.; Kovarova, H.; Sjöstedt, A. An Attenuated Strain of the Facultative Intracellular Bacterium Francisella tularensis Can Escape the Phagosome of Monocytic Cells. Infect. Immun. 2003, 71, 5940-5950. [CrossRef]

7. Santic, M.; Molmeret, M.; Barker, J.R.; Klose, K.E.; Dekanic, A.; Doric, M.; Abu Kwaik, Y. A Francisella tularensis pathogenicity island protein essential for bacterial proliferation within the host cell cytosol. Cell. Microbiol. 2007, 9, 2391-2403. [CrossRef]

8. Santic, M.; Asare, R.; Skrobonja, I.; Jones, S.; Abu Kwaik, Y. Acquisition of the vacuolar ATPase proton pump and phagosome acidification are essential for escape of Francisella tularensis into the macrophage cytosol. Infect. Immun. 2008, 76, 2671-2677. [CrossRef]

9. Gill, V.; Cunha, B.A. Tularemia pneumonia. Semin. Respir. Infect. 1997, 12, 61-67.

10. Stewart, S.J. Tularemia: Association with hunting and farming. FEMS Immunol. Med. Microbiol. 1996, 13, 197-199. [CrossRef]

11. Sandström, G.; Löfgren, S.; Tärnvik, A. A capsule-deficient mutant of Francisella tularensis LVS exhibits enhanced sensitivity to killing by serum but diminished sensitivity to killing by polymorphonuclear leukocytes. Infect. Immun. 1988, 56, 1194-1202. [CrossRef]

12. Su, J.; Yang, J.; Zhao, D.; Kawula, T.H.; Banas, J.A.; Zhang, J.-R. Genome-wide identification of Francisella tularensis virulence determinants. Infect. Immun. 2007, 75, 3089-3101. [CrossRef] [PubMed]

13. Miller, S.I.; Ernst, R.K.; Bader, M.W. LPS, TLR4 and infectious disease diversity. Nat. Rev. Microbiol. 2005, 3, 36-46. [CrossRef] [PubMed]

14. Wang, X.; Ribeiro, A.A.; Guan, Z.; Abraham, S.N.; Raetz, C.R.H. Attenuated virulence of a Francisella mutant lacking the lipid A 4'-phosphatase. Proc. Natl. Acad. Sci. USA 2007, 104, 4136-4141. [CrossRef] [PubMed]

15. Ancuta, P.; Pedron, T.; Girard, R.; Sandström, G.; Chaby, R. Inability of the Francisella tularensis lipopolysaccharide to mimic or to antagonize the induction of cell activation by endotoxins. Infect. Immun. 1996, 64, 2041-2046. [CrossRef] [PubMed]

16. Sandström, G.; Sjöstedt, A.; Johansson, T.; Kuoppa, K.; Williams, J.C. Immunogenicity and toxicity of lipopolysaccharide from Francisella tularensis LVS. FEMS Microbiol. Immunol. 1992, 5, 201-210. [CrossRef] [PubMed]

17. Pierson, T.; Matrakas, D.; Taylor, Y.U.; Manyam, G.; Morozov, V.N.; Zhou, W.; van Hoek, M.L. Proteomic characterization and functional analysis of outer membrane vesicles of Francisella novicida suggests possible role in virulence and use as a vaccine. J. Proteome Res. 2011, 10, 954-967. [CrossRef]

18. Klimentova, J.; Pavkova, I.; Horcickova, L.; Bavlovic, J.; Kofroňová, O.; Benada, O.; Stulik, J. Francisella tularensis subsp. holarctica releases differentially loaded outer membrane vesicles under various stress conditions. Front. Microbiol. 2019, 10. [CrossRef]

19. Lindgren, H.; Golovliov, I.; Baranov, V.; Ernst, R.K.; Telepnev, M.; Sjöstedt, A. Factors affecting the escape of Francisella tularensis from the phagolysosome. J. Med. Microbiol. 2004, 53, 953-958. [CrossRef]

20. Nano, F.E.; Zhang, N.; Cowley, S.C.; Klose, K.E.; Cheung, K.K.M.; Roberts, M.J.; Ludu, J.S.; Letendre, G.W.; Meierovics, A.I.; Stephens, G.; et al. A Francisella tularensis pathogenicity island required for intramacrophage growth. J. Bacteriol. 2004, 186, 6430-6436. [CrossRef]

21. Bröms, J.E.; Sjöstedt, A.; Lavander, M. The Role of the Francisella tularensis Pathogenicity Island in Type VI Secretion, Intracellular Survival, and Modulation of Host Cell Signaling. Front. Microbiol. 2010, 1. [CrossRef]

22. de Bruin, O.M.; Ludu, J.S.; Nano, F.E. The Francisella pathogenicity island protein IglA localizes to the bacterial cytoplasm and is needed for intracellular growth. BMC Microbiol. 2007, 7, 1. [CrossRef] [PubMed]

23. Larsson, P.; Elfsmark, D.; Svensson, K.; Wikström, P.; Forsman, M.; Brettin, T.; Keim, P.; Johansson, A. Molecular Evolutionary Consequences of Niche Restriction in Francisella tularensis, a Facultative Intracellular Pathogen. PLoS Pathog. 2009, 5. [CrossRef] [PubMed] 
24. Larsson, P.; Oyston, P.C.F.; Chain, P.; Chu, M.C.; Duffield, M.; Fuxelius, H.-H.; Garcia, E.; Hälltorp, G.; Johansson, D.; Isherwood, K.E.; et al. The complete genome sequence of Francisella tularensis, the causative agent of tularemia. Nat. Genet. 2005, 37, 153-159. [CrossRef] [PubMed]

25. Santic, M.; Molmeret, M.; Klose, K.E.; Jones, S.; Kwaik, Y.A. The Francisella tularensis pathogenicity island protein IglC and its regulator MglA are essential for modulating phagosome biogenesis and subsequent bacterial escape into the cytoplasm. Cell. Microbiol. 2005, 7, 969-979. [CrossRef] [PubMed]

26. Bröms, J.E.; Lavander, M.; Meyer, L.; Sjöstedt, A. IglG and IglI of the Francisella Pathogenicity Island Are Important Virulence Determinants of Francisella tularensis LVS. Infect. Immun. 2011, 79, 3683-3696. [CrossRef] [PubMed]

27. Lauriano, C.M.; Barker, J.R.; Yoon, S.-S.; Nano, F.E.; Arulanandam, B.P.; Hassett, D.J.; Klose, K.E. $\mathrm{MglA}$ regulates transcription of virulence factors necessary for Francisella tularensis intraamoebae and intramacrophage survival. Proc. Natl. Acad. Sci. USA 2004, 101, 4246-4249. [CrossRef]

28. Brotcke, A.; Weiss, D.S.; Kim, C.C.; Chain, P.; Malfatti, S.; Garcia, E.; Monack, D.M. Identification of MglA-regulated genes reveals novel virulence factors in Francisella tularensis. Infect. Immun. 2006, 74, 6642-6655. [CrossRef]

29. Guina, T.; Radulovic, D.; Bahrami, A.J.; Bolton, D.L.; Rohmer, L.; Jones-Isaac, K.A.; Chen, J.; Gallagher, L.A.; Gallis, B.; Ryu, S.; et al. MglA regulates Francisella tularensis subsp. novicida (Francisella novicida) response to starvation and oxidative stress. J. Bacteriol. 2007, 189, 6580-6586. [CrossRef]

30. Charity, J.C.; Costante-Hamm, M.M.; Balon, E.L.; Boyd, D.H.; Rubin, E.J.; Dove, S.L. Twin RNA polymerase-associated proteins control virulence gene expression in Francisella tularensis. PLoS Pathog. 2007, 3, e84. [CrossRef]

31. Brotcke, A.; Monack, D.M. Identification of fevR, a novel regulator of virulence gene expression in Francisella novicida. Infect. Immun. 2008, 76, 3473-3480. [CrossRef]

32. Charity, J.C.; Blalock, L.T.; Costante-Hamm, M.M.; Kasper, D.L.; Dove, S.L. Small molecule control of virulence gene expression in Francisella tularensis. PLoS Pathog. 2009, 5, e1000641. [CrossRef]

33. Dai, S.; Mohapatra, N.P.; Schlesinger, L.S.; Gunn, J.S. Regulation of Francisella tularensis virulence. Front. Microbiol. 2010, 1, 144. [CrossRef]

34. Baron, G.S.; Nano, F.E. MglA and MglB are required for the intramacrophage growth of Francisella novicida. Mol. Microbiol. 1998, 29, 247-259. [CrossRef] [PubMed]

35. Bönquist, L.; Lindgren, H.; Golovliov, I.; Guina, T.; Sjöstedt, A. MglA and Igl proteins contribute to the modulation of Francisella tularensis live vaccine strain-containing phagosomes in murine macrophages. Infect. Immun. 2008, 76, 3502-3510. [CrossRef] [PubMed]

36. Cuthbert, B.J.; Brennan, R.G.; Schumacher, M.A. Structural and Biochemical Characterization of the Francisella tularensis Pathogenicity Regulator, Macrophage Locus Protein A (MglA). PLoS ONE 2015, 10, e0128225. [CrossRef] [PubMed]

37. Rohlfing, A.E.; Dove, S.L. Coordinate control of virulence gene expression in Francisella tularensis involves direct interaction between key regulators. J. Bacteriol. 2014, 196, 3516-3526. [CrossRef] [PubMed]

38. Ramsey, K.M.; Osborne, M.L.; Vvedenskaya, I.O.; Su, C.; Nickels, B.E.; Dove, S.L. Ubiquitous Promoter-Localization of Essential Virulence Regulators in Francisella tularensis. PLoS Pathog. 2015, 11. [CrossRef]

39. Cuthbert, B.J.; Ross, W.; Rohlfing, A.E.; Dove, S.L.; Gourse, R.L.; Brennan, R.G.; Schumacher, M.A. Dissection of the molecular circuitry controlling virulence in Francisella tularensis. Genes Dev. 2017, 31, 1549-1560. [CrossRef]

40. Wrench, A.P.; Gardner, C.L.; Siegel, S.D.; Pagliai, F.A.; Malekiha, M.; Gonzalez, C.F.; Lorca, G.L. MglA/SspA Complex Interactions Are Modulated by Inorganic Polyphosphate. PLoS ONE 2013, 8. [CrossRef] [PubMed]

41. Faron, M.; Fletcher, J.R.; Rasmussen, J.A.; Long, M.E.; Allen, L.-A.H.; Jones, B.D. The Francisella tularensis migR, trmE, and cphA Genes Contribute to F. tularensis Pathogenicity Island Gene Regulation and Intracellular Growth by Modulation of the Stress Alarmone ppGpp. Infect. Immun 2013, 81, 2800-2811. [CrossRef] [PubMed]

42. Stojkova, P.; Spidlova, P.; Lenco, J.; Rehulkova, H.; Kratka, L.; Stulik, J. HU protein is involved in intracellular growth and full virulence of Francisella tularensis. Virulence 2018, 9, 754-770. [CrossRef] [PubMed] 
43. Meibom, K.L.; Forslund, A.-L.; Kuoppa, K.; Alkhuder, K.; Dubail, I.; Dupuis, M.; Forsberg, A.; Charbit, A. Hfq, a novel pleiotropic regulator of virulence-associated genes in Francisella tularensis. Infect. Immun. 2009, 77, 1866-1880. [CrossRef] [PubMed]

44. Lenco, J.; Tambor, V.; Link, M.; Klimentova, J.; Dresler, J.; Peterek, M.; Charbit, A.; Stulik, J. Changes in proteome of the $\Delta \mathrm{hfq}$ strain derived from Francisella tularensis LVS correspond with its attenuated phenotype. Proteomics 2014, 14, 2400-2409. [CrossRef] [PubMed]

45. Chambers, J.R.; Bender, K.S. The RNA Chaperone Hfq Is Important for Growth and Stress Tolerance in Francisella novicida. PLoS ONE 2011, 6. [CrossRef]

46. Mortensen, B.L.; Fuller, J.R.; Taft-Benz, S.; Kijek, T.M.; Miller, C.N.; Huang, M.T.H.; Kawula, T.H. Effects of the Putative Transcriptional Regulator IclR on Francisella tularensis Pathogenesis. Infect. Immun. 2010, 78, 5022. [CrossRef]

47. Weiss, D.S.; Brotcke, A.; Henry, T.; Margolis, J.J.; Chan, K.; Monack, D.M. In vivo negative selection screen identifies genes required for Francisella virulence. Proc. Natl. Acad. Sci. USA 2007, 104, 6037-6042. [CrossRef]

48. Fuller, J.R. Characterization of the Francisella Virulence Factor RipA. Ph.D. Thesis, University of North Carolina, Chapel Hill, NC, USA, 2008. [CrossRef]

49. Ma, Z.; Russo, V.C.; Rabadi, S.M.; Jen, Y.; Catlett, S.V.; Bakshi, C.S.; Malik, M. Elucidation of a mechanism of oxidative stress regulation in Francisella tularensis live vaccine strain. Mol. Microbiol. 2016, 101, 856-878. [CrossRef]

50. Lindgren, H.; Shen, H.; Zingmark, C.; Golovliov, I.; Conlan, W.; Sjöstedt, A. Resistance of Francisella tularensis strains against reactive nitrogen and oxygen species with special reference to the role of KatG. Infect. Immun. 2007, 75, 1303-1309. [CrossRef]

51. Marghani, D. Characterization of the Role of Transcriptional Regulator of AraC/XylS Family in Tularemia Pathogenesis. Ph.D. Thesis, Touro College, New York, NY, USA, 2019.

52. Pérard, J.; Nader, S.; Levert, M.; Arnaud, L.; Carpentier, P.; Siebert, C.; Blanquet, F.; Cavazza, C.; Renesto, P.; Schneider, D.; et al. Structural and functional studies of the metalloregulator Fur identify a promoter-binding mechanism and its role in Francisella tularensis virulence. Commun. Biol. 2018, 1. [CrossRef]

53. Sullivan, J.T.; Jeffery, E.F.; Shannon, J.D.; Ramakrishnan, G. Characterization of the siderophore of Francisella tularensis and role of fslA in siderophore production. J. Bacteriol. 2006, 188, 3785-3795. [CrossRef] [PubMed]

54. Ramakrishnan, G.; Sen, B.; Johnson, R. Paralogous outer membrane proteins mediate uptake of different forms of iron and synergistically govern virulence in Francisella tularensis tularensis. J. Biol. Chem. 2012, 287, 25191-25202. [CrossRef]

55. Lindgren, H.; Honn, M.; Salomonsson, E.; Kuoppa, K.; Forsberg, Å.; Sjöstedt, A. Iron Content Differs between Francisella tularensis Subspecies tularensis and Subspecies holarctica Strains and Correlates to Their Susceptibility to $\mathrm{H}_{2} \mathrm{O}_{2}$-Induced Killing. Infect. Immun. 2011, 79, 1218-1224. [CrossRef] [PubMed]

56. Mukhamedyarov, D.; Makarova, K.S.; Severinov, K.; Kuznedelov, K. Francisella RNA polymerase contains a heterodimer of non-identical $\alpha$ subunits. BMC Mol. Biol. 2011, 12, 50. [CrossRef]

57. Grall, N.; Livny, J.; Waldor, M.; Barel, M.; Charbit, A.; Meibom, K.L. Pivotal role of the Francisella tularensis heat-shock sigma factor RpoH. Microbiology 2009, 155, 2560-2572. [CrossRef]

58. Nonaka, G.; Blankschien, M.; Herman, C.; Gross, C.A.; Rhodius, V.A. Regulon and promoter analysis of the E. coli heat-shock factor, sigma32, reveals a multifaceted cellular response to heat stress. Genes Dev. 2006, 20 , 1776-1789. [CrossRef]

59. Alam, A.; Golovliov, I.; Javed, E.; Kumar, R.; Ådén, J.; Sjöstedt, A. Dissociation between the critical role of $\mathrm{ClpB}$ of Francisella tularensis for the heat shock response and the DnaK interaction and its important role for efficient type VI secretion and bacterial virulence. PLoS Pathog. 2020, 16, e1008466. [CrossRef]

60. Durham-Colleran, M.W.; Verhoeven, A.B.; van Hoek, M.L. Francisella novicida forms in vitro biofilms mediated by an orphan response regulator. Microb. Ecol. 2010, 59, 457-465. [CrossRef]

61. Bell, B.L.; Mohapatra, N.P.; Gunn, J.S. Regulation of virulence gene transcripts by the Francisella novicida orphan response regulator PmrA: Role of phosphorylation and evidence of MglA/SspA interaction. Infect. Immun. 2010, 78, 2189-2198. [CrossRef]

62. Zogaj, X.; Wyatt, G.C.; Klose, K.E. Cyclic di-GMP stimulates biofilm formation and inhibits virulence of Francisella novicida. Infect. Immun. 2012, 80, 4239-4247. [CrossRef] [PubMed] 
63. Ramsey, K.M.; Dove, S.L. A response regulator promotes Francisella tularensis intramacrophage growth by repressing an anti-virulence factor. Mol. Microbiol. 2016, 101, 688-700. [CrossRef]

64. Hoang, K.V.; Fitch, J.; White, P.; Mohapatra, N.P.; Gunn, J.S. The sensor kinase QseC regulates the unlinked PmrA response regulator and downstream gene expression in Francisella. J. Bacteriol. 2020. [CrossRef] [PubMed]

65. Freeman, Z.N.; Dorus, S.; Waterfield, N.R. The KdpD/KdpE Two-Component System: Integrating K+ Homeostasis and Virulence. PLoS Pathog. 2013, 9, e1003201. [CrossRef] [PubMed]

66. Dean, S.N.; Milton, M.E.; Cavanagh, J.; van Hoek, M.L. Francisella novicida Two-Component System Response Regulator BfpR Modulates iglC Gene Expression, Antimicrobial Peptide Resistance, and Biofilm Production. Front. Cell Infect. Microbiol. 2020, 10. [CrossRef] [PubMed]

67. De Reuse, H.; Taha, M.K. RegF, an SspA homologue, regulates the expression of the Neisseria gonorrhoeae pilE gene. Res. Microbiol. 1997, 148, 289-303. [CrossRef]

68. Merrell, D.S.; Hava, D.L.; Camilli, A. Identification of novel factors involved in colonization and acid tolerance of Vibrio cholerae. Mol. Microbiol. 2002, 43, 1471-1491. [CrossRef]

69. Xu, Q.; Dziejman, M.; Mekalanos, J.J. Determination of the transcriptome of Vibrio cholerae during intraintestinal growth and midexponential phase in vitro. Proc. Natl. Acad. Sci. USA 2003, 100, 1286-1291. [CrossRef]

70. Hansen, A.-M.; Jin, D.J. SspA up-regulates gene expression of the LEE pathogenicity island by decreasing H-NS levels in enterohemorrhagic Escherichia coli. BMC Microbiol. 2012, 12, 231. [CrossRef]

71. Hansen, A.-M.; Qiu, Y.; Yeh, N.; Blattner, F.R.; Durfee, T.; Jin, D.J. SspA is required for acid resistance in stationary phase by downregulation of H-NS in Escherichia coli. Mol. Microbiol. 2005, 56, 719-734. [CrossRef]

72. Honn, M.; Lindgren, H.; Sjöstedt, A. The role of MglA for adaptation to oxidative stress of Francisella tularensis LVS. BMC Microbiol. 2012, 12, 14. [CrossRef]

73. Paul, B.J.; Berkmen, M.B.; Gourse, R.L. DksA potentiates direct activation of amino acid promoters by ppGpp. Proc. Natl. Acad. Sci. USA 2005, 102, 7823-7828. [CrossRef]

74. Srivatsan, A.; Wang, J.D. Control of bacterial transcription, translation and replication by (p)ppGpp. Curr. Opin. Microbiol. 2008, 11, 100-105. [CrossRef]

75. Rohmer, L.; Brittnacher, M.; Svensson, K.; Buckley, D.; Haugen, E.; Zhou, Y.; Chang, J.; Levy, R.; Hayden, H.; Forsman, M.; et al. Potential source of Francisella tularensis live vaccine strain attenuation determined by genome comparison. Infect. Immun. 2006, 74, 6895-6906. [CrossRef] [PubMed]

76. Dean, R.E.; Ireland, P.M.; Jordan, J.E.; Titball, R.W.; Oyston, P.C.F. RelA regulates virulence and intracellular survival of Francisella novicida. Microbiology 2009, 155, 4104-4113. [CrossRef] [PubMed]

77. Buchan, B.W.; McCaffrey, R.L.; Lindemann, S.R.; Allen, L.-A.H.; Jones, B.D. Identification of migR, a regulatory element of the Francisella tularensis live vaccine strain iglABCD virulence operon required for normal replication and trafficking in macrophages. Infect. Immun. 2009, 77, 2517-2529. [CrossRef] [PubMed]

78. Michán, C.; Manchado, M.; Dorado, G.; Pueyo, C. In Vivo Transcription of the Escherichia coli oxyRRegulon as a Function of Growth Phase and in Response to Oxidative Stress. J. Bacteriol. 1999, 181, 2759-2764. [CrossRef] [PubMed]

79. Honn, M.; Lindgren, H.; Bharath, G.K.; Sjöstedt, A. Lack of OxyR and KatG Results in Extreme Susceptibility of Francisella tularensis LVS to Oxidative Stress and Marked Attenuation In Vivo. Front. Cell Infect. Microbiol. 2017, 7. [CrossRef] [PubMed]

80. Alharbi, A.; Rabadi, S.M.; Alqahtani, M.; Marghani, D.; Worden, M.; Ma, Z.; Malik, M.; Bakshi, C.S. Role of peroxiredoxin of the AhpC/TSA family in antioxidant defense mechanisms of Francisella tularensis. PLoS ONE 2019, 14. [CrossRef] [PubMed]

81. Carlson, P.E.; Horzempa, J.; O’Dee, D.M.; Robinson, C.M.; Neophytou, P.; Labrinidis, A.; Nau, G.J. Global Transcriptional Response to Spermine, a Component of the Intramacrophage Environment, Reveals Regulation of Francisella Gene Expression through Insertion Sequence Elements. J. Bacteriol. 2009, 191, 6855-6864. [CrossRef]

82. Igarashi, K.; Kashiwagi, K. Polyamines: Mysterious modulators of cellular functions. Biochem. Biophys. Res. Commun. 2000, 271, 559-564. [CrossRef]

83. Mahillon, J.; Chandler, M. Insertion sequences. Microbiol. Mol. Biol. Rev. 1998, 62, 725-774. [CrossRef] [PubMed] 
84. de Fernandez, M.T.F.; Eoyang, L.; August, J.T. Factor fraction required for the synthesis of bacteriophage Qbeta-RNA. Nature 1968, 219, 588-590. [CrossRef] [PubMed]

85. Azam, T.A.; Ishihama, A. Twelve species of the nucleoid-associated protein from Escherichia coli. Sequence recognition specificity and DNA binding affinity. J. Biol. Chem. 1999, 274, 33105-33113. [CrossRef] [PubMed]

86. Updegrove, T.B.; Correia, J.J.; Galletto, R.; Bujalowski, W.; Wartell, R.M. E. coli DNA associated with isolated Hfq interacts with Hfq's distal surface and C-terminal domain. Biochim. Biophys. Acta 2010, 1799, 588-596. [CrossRef]

87. Diestra, E.; Cayrol, B.; Arluison, V.; Risco, C. Cellular electron microscopy imaging reveals the localization of the Hfq protein close to the bacterial membrane. PLoS ONE 2009, 4, e8301. [CrossRef] [PubMed]

88. Schiano, C.A.; Bellows, L.E.; Lathem, W.W. The small RNA chaperone Hfq is required for the virulence of Yersinia pseudotuberculosis. Infect. Immun. 2010, 78, 2034-2044. [CrossRef] [PubMed]

89. Mellin, J.R.; McClure, R.; Lopez, D.; Green, O.; Reinhard, B.; Genco, C. Role of Hfq in iron-dependent and -independent gene regulation in Neisseria meningitidis. Microbiol. 2010, 156, 2316-2326. [CrossRef]

90. Sittka, A.; Pfeiffer, V.; Tedin, K.; Vogel, J. The RNA chaperone Hfq is essential for the virulence of Salmonella typhimurium. Mol. Microbiol. 2007, 63, 193-217. [CrossRef]

91. Gottesman, S.; Storz, G. Bacterial Small RNA Regulators: Versatile Roles and Rapidly Evolving Variations. Cold Spring Harb. Perspect. Biol. 2011, 3. [CrossRef]

92. Soper, T.J.; Woodson, S.A. The rpoS mRNA leader recruits Hfq to facilitate annealing with DsrA sRNA. RNA 2008, 14, 1907-1917. [CrossRef]

93. Pettijohn, D.E. Histone-like Proteins and Bacterial Chromosome Structure. J. Biol. Chem. 1988, 263, 12793-12796. [PubMed]

94. Dillon, S.C.; Dorman, C.J. Bacterial nucleoid-associated proteins, nucleoid structure and gene expression. Nat. Rev. Microbiol. 2010, 8, 185-195. [CrossRef] [PubMed]

95. Bonnefoy, E.; Rouvière-Yaniv, J. HU and IHF, two homologous histone-like proteins of Escherichia coli, form different protein-DNA complexes with short DNA fragments. EMBO J. 1991, 10, 687-696. [CrossRef] [PubMed]

96. Stojkova, P.; Spidlova, P.; Stulik, J. Nucleoid-Associated Protein HU: A Lilliputian in Gene Regulation of Bacterial Virulence. Front. Cell. Infect. Microbiol. 2019, 9. [CrossRef] [PubMed]

97. Bhowmick, T.; Ghosh, S.; Dixit, K.; Ganesan, V.; Ramagopal, U.A.; Dey, D.; Sarma, S.P.; Ramakumar, S.; Nagaraja, V. Targeting Mycobacterium tuberculosis nucleoid-associated protein HU with structure-based inhibitors. Nat. Commun. 2014, 5, 4124. [CrossRef]

98. Oberto, J.; Nabti, S.; Jooste, V.; Mignot, H.; Rouviere-Yaniv, J. The HU regulon is composed of genes responding to anaerobiosis, acid stress, high osmolarity and SOS induction. PLOS ONE 2009, 4, e4367. [CrossRef]

99. Broyles, S.S.; Pettijohn, D.E. Interaction of the Escherichia coli HU protein with DNA. Evidence for formation of nucleosome-like structures with altered DNA helical pitch. J. Mol. Biol. 1986, 187, 47-60. [CrossRef]

100. Bonnefoy, E.; Rouvière-Yaniv, J. HU, the major histone-like protein of E. coli, modulates the binding of IHF to oriC. EMBO J. 1992, 11, 4489-4496. [CrossRef]

101. Balandina, A.; Kamashev, D.; Rouviere-Yaniv, J. The Bacterial Histone-like Protein HU Specifically Recognizes Similar Structures in All Nucleic Acids DNA, RNA, And Their Hybrids. J. Biol. Chem. 2002, 277, 27622-27628. [CrossRef]

102. Kamashev, D.; Rouviere-Yaniv, J. The histone-like protein HU binds specifically to DNA recombination and repair intermediates. EMBO J. 2000, 19, 6527-6535. [CrossRef]

103. Rouvière-Yaniv, J.; Yaniv, M.; Germond, J.-E. E. coli DNA binding protein HU forms nucleosome-like structure with circular double-stranded DNA. Cell 1979, 17, 265-274. [CrossRef]

104. Boubrik, F.; Rouviere-Yaniv, J. Increased sensitivity to gamma irradiation in bacteria lacking protein HU. Proc. Natl. Acad. Sci. USA 1995, 92, 3958-3962. [CrossRef] [PubMed]

105. Lavoie, B.D.; Shaw, G.S.; Millner, A.; Chaconas, G. Anatomy of a flexer-DNA complex inside a higher-order transposition intermediate. Cell 1996, 85, 761-771. [CrossRef]

106. Chen, C.; Ghosh, S.; Grove, A. Substrate specificity of Helicobacter pylori histone-like HU protein is determined by insufficient stabilization of DNA flexure points. Biochem. J. 2004, 383, 343-351. [CrossRef] [PubMed] 
107. Grove, A.; Saavedra, T.C. The Role of Surface-Exposed Lysines in Wrapping DNA about the Bacterial Histone-Like Protein HU. Biochemistry 2002, 41, 7597-7603. [CrossRef] [PubMed]

108. Krylov, A.S.; Zasedateleva, O.A.; Prokopenko, D.V.; Rouviere-Yaniv, J.; Mirzabekov, A.D. Massive parallel analysis of the binding specificity of histone-like protein HU to single- and double-stranded DNA with generic oligodeoxyribonucleotide microchips. Nucleic Acids Res. 2001, 29, 2654-2660. [CrossRef] [PubMed]

109. Berger, M.; Gerganova, V.; Berger, P.; Rapiteanu, R.; Lisicovas, V.; Dobrindt, U. Genes on a Wire: The Nucleoid-Associated Protein HU Insulates Transcription Units in Escherichia coli. Sci. Rep. 2016, 6, 31512. [CrossRef]

110. Toyofuku, M.; Roschitzki, B.; Riedel, K.; Eberl, L. Identification of proteins associated with the Pseudomonas aeruginosa biofilm extracellular matrix. J. Proteome Res. 2012, 11, 4906-4915. [CrossRef]

111. Beckmann, J.F.; Markowski, T.W.; Witthuhn, B.A.; Fallon, A.M. Detection of the wolbachia-encoded dna binding protein, hu beta, in mosquito gonads. Insect Biochem. Mol. Biol. 2013, 43, 272-279. [CrossRef]

112. Konecna, K.; Hernychova, L.; Reichelova, M.; Lenco, J.; Klimentova, J.; Stulik, J.; Macela, A.; Alefantis, T.; Delvecchio, V.G. Comparative proteomic profiling of culture filtrate proteins of less and highly virulent Francisella tularensis strains. Proteomics 2010, 10, 4501-4511. [CrossRef]

113. Milanez, G.P.; Werle, C.H.; Amorim, M.R.; Ribeiro, R.A.; Tibo, L.H.S.; Roque-Barreira, M.C.; Oliveira, A.F.; Brocchi, M. HU-Lacking Mutants of Salmonella enterica Enteritidis Are Highly Attenuated and Can Induce Protection in Murine Model of Infection. Front. Microbiol. 2018, 9. [CrossRef] [PubMed]

114. Dieppedale, J.; Gesbert, G.; Ramond, E.; Chhuon, C.; Dubail, I.; Dupuis, M.; Guerrera, I.C.; Charbit, A. Possible Links Between Stress Defense and the Tricarboxylic Acid (TCA) Cycle in Francisella Pathogenesis. Mol. Cell Proteom. 2013, 12, 2278-2292. [CrossRef]

115. Porcheron, G.; Dozois, C.M. Interplay between Iron Homeostasis and Virulence: Fur and RyhB as Major Regulators of Bacterial Pathogenicity. Available online: https:/pubmed.ncbi.nlm.nih.gov/25888312/ (accessed on 22 June 2020).

116. Troxell, B.; Hassan, H.M. Transcriptional regulation by Ferric Uptake Regulator (Fur) in pathogenic bacteria. Front. Cell Infect. Microbiol. 2013, 3. [CrossRef] [PubMed]

117. Troxell, B.; Sikes, M.L.; Fink, R.C.; Vazquez-Torres, A.; Jones-Carson, J.; Hassan, H.M. Fur negatively regulates hns and is required for the expression of HilA and virulence in Salmonella enterica serovar Typhimurium. J. Bacteriol. 2011, 193, 497-505. [CrossRef] [PubMed]

118. Troxell, B.; Fink, R.C.; Porwollik, S.; McClelland, M.; Hassan, H.M. The Fur regulon in anaerobically grown Salmonella enterica sv. Typhimurium: Identification of new Fur targets. BMC Microbiol. 2011, 11, 236. [CrossRef] [PubMed]

119. Dubrac, S.; Touati, D. Fur Positive Regulation of Iron Superoxide Dismutase in Escherichia coli: Functional Analysis of thesodB Promoter. J. Bacteriol. 2000, 182, 3802-3808. [CrossRef]

120. Pan, X.; Tamilselvam, B.; Hansen, E.J.; Daefler, S. Modulation of iron homeostasis in macrophages by bacterial intracellular pathogens. BMC Microbiol. 2010, 10, 64. [CrossRef]

121. Ramakrishnan, G.; Meeker, A.; Dragulev, B. fslE is necessary for siderophore-mediated iron acquisition in Francisella tularensis Schu S4. J. Bacteriol. 2008, 190, 5353-5361. [CrossRef]

122. Molina-Henares, A.J.; Krell, T.; Guazzaroni, M.E.; Segura, A.; Ramos, J.L. Members of the IclR family of bacterial transcriptional regulators function as activators and/or repressors. FEMS Microbiol. Rev. 2006, 30, 157-186. [CrossRef]

123. Harrison, S.C.; Aggarwal, A.K. DNA recognition by proteins with the helix-turn-helix motif. Annu. Rev. Biochem. 1990, 59, 933-969. [CrossRef]

124. Gray, C.G.; Cowley, S.C.; Cheung, K.K.M.; Nano, F.E. The identification of five genetic loci of Francisella novicida associated with intracellular growth. FEMS Microbiol. Lett. 2002, 215, 53-56. [CrossRef] [PubMed]

125. Alam, A.; Golovliov, I.; Javed, E.; Sjöstedt, A. ClpB mutants of Francisella tularensis subspecies holarctica and tularensis are defective for type VI secretion and intracellular replication. Sci. Rep. 2018, 8, 11324. [CrossRef] [PubMed]

126. Eneslätt, K.; Golovliov, I.; Rydén, P.; Sjöstedt, A. Vaccine-Mediated Mechanisms Controlling Replication of Francisella tularensis in Human Peripheral Blood Mononuclear Cells Using a Co-culture System. Front. Cell Infect. Microbiol. 2018, 8, 27. [CrossRef] [PubMed] 
127. Lindgren, H.; Eneslätt, K.; Golovliov, I.; Gelhaus, C.; Rydén, P.; Wu, T.; Sjöstedt, A. Vaccine-Mediated Mechanisms Controlling Francisella tularensis SCHU S4 Growth in a Rat Co-Culture System. Pathogens 2020, 9, 338. [CrossRef] [PubMed]

128. Stock, A.M.; Robinson, V.L.; Goudreau, P.N. Two-component signal transduction. Annu. Rev. Biochem. 2000, 69, 183-215. [CrossRef] [PubMed]

129. van Hoek, M.L.; Hoang, K.V.; Gunn, J.S. Two-Component Systems in Francisella Species. Front. Cell Infect. Microbiol. 2019, 9, 198. [CrossRef] [PubMed]

130. Gao, R.; Stock, A.M. Biological insights from structures of two-component proteins. Annu. Rev. Microbiol. 2009, 63, 133-154. [CrossRef]

131. Alkhuder, K.; Meibom, K.L.; Dubail, I.; Dupuis, M.; Charbit, A. Identification of trkH, Encoding a Potassium Uptake Protein Required for Francisella tularensis Systemic Dissemination in Mice. PLoS ONE 2010, 5. [CrossRef]

132. Mohapatra, N.P.; Soni, S.; Bell, B.L.; Warren, R.; Ernst, R.K.; Muszynski, A.; Carlson, R.W.; Gunn, J.S. Identification of an orphan response regulator required for the virulence of Francisella spp. and transcription of pathogenicity island genes. Infect. Immun. 2007, 75, 3305-3314. [CrossRef]

133. Sammons-Jackson, W.L.; McClelland, K.; Manch-Citron, J.N.; Metzger, D.W.; Bakshi, C.S.; Garcia, E.; Rasley, A.; Anderson, B.E. Generation and characterization of an attenuated mutant in a response regulator gene of Francisella tularensis live vaccine strain (LVS). DNA Cell Biol. 2008, 27, 387-403. [CrossRef]

Publisher's Note: MDPI stays neutral with regard to jurisdictional claims in published maps and institutional affiliations. 